\title{
Research on the Application and Problems of Equity Incentives in China's NEEQ Companies
}

\author{
Jizhong Li \\ Investment Banking Division, Guorong Securities Co., Ltd., Beijing, China \\ Email address: \\ jizhongli518@163.com
}

To cite this article:

Jizhong Li. Research on the Application and Problems of Equity Incentives in China's NEEQ Companies. International Journal of Economics, Finance and Management Sciences. Vol. 7, No. 1, 2019, pp. 16-20. doi: 10.11648/j.ijefm.20190701.14

Received: January 25, 2019; Accepted: February 25, 2019; Published: March 8, 2019

\begin{abstract}
Currently, listed companies are implementing the governance structure of board of directors, under which the specific management work is undertaken by managers. This enables managers to play an extremely crucial role in company management, and the extent of their work enthusiasm is directly related to management efficiency and quality. In order to improve the work enthusiasm of managers, many enterprises have been adopting the method of equity incentives as a long-term move to stimulate professional managers and have achieved positive incentive effects. In recent years, following the development of domestic capital market, the equity incentive measure has been widely adopted in National Equities Exchange And Quotations (hereinafter referred to as NEEQ) companies. Based on such situation, this paper will analyze the equity incentives of NEEQ companies, and explore their specific strategies and applicable conditions, etc.
\end{abstract}

Keywords: NEEQ Companies, Equity Incentives, Application Mechanism

\section{Introduction}

Nowadays, following the development of modern management theory system, equity incentive has become one of the incentive measures of many A-share listed companies and a significant part of their incentive and constraint mechanism [1], and has been playing a critical role in improving their management. However, the application of equity incentive in the National Equities Exchange And Quotations (hereinafter referred to as NEEQ) company is relatively few [2]. On the one hand, it is influenced by the development process of the NEEQ market, on the other hand, it is also restricted by the liquidity of the current NEEQ market [3]. In view of this, combined with the actual situation of the NEEQ listed company, exploring the equity incentive strategy suitable for the application of the NEEQ company has a vital role in giving full play to the incentive and restraint role of equity incentive for small and medium-sized enterprises in China, and improving the management level of small and medium-sized enterprises [4]. On the basis of summing up the previous theoretical research on equity incentive, this paper deeply analyses the positive role of equity incentive in motivating employees and companies, and then combines with the current situation of the implementation of equity incentive in the NEEQ listed companies, analyses the motivation and preference of the NEEQ companies in the choice of equity incentive mode, and points out the existing problems in the application of equity incentive in the current NEEQ market. After that, it puts forward the targeted solutions and improvement strategies..

\section{Equity Incentive Summary}

\subsection{Concept of Equity Incentive}

From the perspective of subordination relations, equity incentive falls into the category of waiver incentive, and is one of the common measures adopted by enterprises for long-term incentive of employees. This practice is mostly used for stimulating and constraining managers and technical backbone personnel. It can connect the above-mentioned personnel closely with corporate development, bring their maximum value into play and achieve the rapid development of enterprises [5].

\subsection{Common Forms of Equity Incentive}

\subsubsection{Stock Option}

The term "stock option" refers to the right granted by a 
company to individual employees to purchase a certain amount of its stock shares at a preferential price. Such stocks can only be held by the said employees, and shall not be used for circulation purposes including transfer, pledge and guarantee [6]. The employees can only acquire corresponding dividends by owning stock shares. Stock option is one of the significant means to consolidate the interest relationship between enterprises and employees, and can stimulate employees to have better work performance. Certainly, stock option is not compulsory. Employees can decide of their own free will whether to purchase company stocks.

\subsubsection{Restricted Stock}

Compared with stock option, there is relatively less restriction on restricted stock. Enterprises sell a certain amount of company stock shares to employees at a price lower than the secondary market and have these stock shares locked for certain duration. When the set conditions are satisfied, such stock shares will be unlocked and employees can decide of their own free will whether to sell or hold them. This type of equity incentive is subscribed by employees through self-raised funds, and can only be unlocked according to the agreed time limit and proportion after certain evaluation indicators are satisfied [7].

\subsubsection{Employee Stock Ownership Plan}

The term "employee stock ownership plan" means that employees decide of their own free will to subscribe for part of the company equity, and establish an exclusive employee stock ownership management institution, which will participate in the company board of directors on behalf of employees to make management decisions and enjoy dividend income [8].

\subsubsection{Stock Appreciation Right}

The incentive effects of stock appreciation right on company managers are the most remarkable. This practice connects the economic benefits brought about by company development with personal efforts [9]. Only when enterprises achieve certain operating results within certain duration can company managers acquire corresponding equity. This can stimulate managers to wholeheartedly engage in company development management and result in the improvement of company performance or the rise of company stock price, thereby yielding corresponding agreed income.

\subsubsection{Phantom Equity}

Strictly speaking, phantom equity is not a type of equity. It is a mutual agreement between enterprises and incentive objects, and there is no factual ownership. Companies first grant phantom equity to certain incentive objects. When company performance satisfies the agreement between the two parties, they will pay dividend rewards to incentive objects by reference to stock returns in the light of the proportion of phantom equity [10]. Phantom equity will not take up the actual company stock, and holders will not have corresponding decision-making right and ownership. When a holder's employment relationship with the company is terminated, phantom equity will become null and void automatically.

\subsubsection{Incentive Fund}

As a special incentive measure, incentive fund is contributed by both enterprises and incentive objects. Specifically, companies withdraw a certain proportion from their development profits to form the incentive fund and grant such fund to incentive objects in a lump sum or through multiple times, and incentive objects are required to proportionally pay certain self-raised funds to purchase company stock shares. Stock shares purchased through the above-mentioned method can be owned by incentive objects only after a certain duration of lock-up period. Figure 1 show that the a-share market favours restricted stock, at 76.66 percent [11].

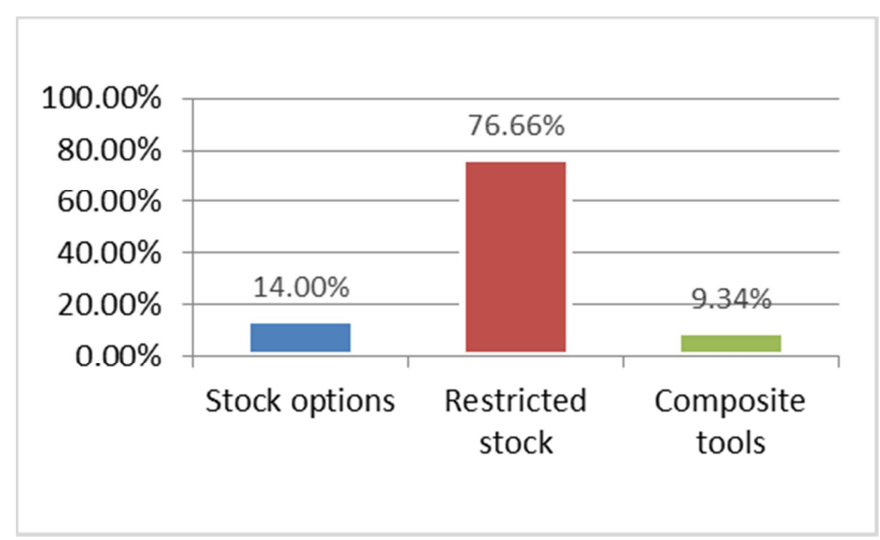

Figure 1. A - share market equity incentive plan distribution in 2017.

\section{Analysis of Equity Incentive's Effects on Incentive Objects and Companies}

\subsection{Incentive Effects}

Whichever form of equity incentive it is, the fundamental purposes are to connect objective objects with enterprises to achieve benefit sharing, have long-term incentive effects to retain talents and bring their value into play, and provide human resource foundation for enterprise development [12]. This is an effective incentive to incentive object from the material level. By connecting the benefits of enterprises and individuals together, it enables incentive objects to enjoy the profits brought about by development jointly with enterprises and make concerted efforts to achieve the operating objectives, thereby propelling the rapid development of enterprises and achieving the win-win outcome for enterprises and incentive objectives.

\subsection{Constraint Effects}

In general, when deciding the remuneration for managers or backbone personnel, apart from regular salary and benefit systems, there will be certain agreement on equity incentive, which is a significant constituent part of the remuneration system and takes up a considerable proportion. However, due 
to the existence of operating risks, there is possibility that the operating objective of enterprises cannot be achieved. For incentive objects, equity incentive is not something that only brings about benefits but no harms [13]. If company development cannot achieve the anticipated requirements, incentive objects also need to bear relevant losses and share corresponding operating risks. This will stimulate relevant personnel to work hard while constraining their specific conducts and work performance.

\subsection{Reduce Commission and Agency Cost}

Achieving the benefit and risk sharing between incentive objects and enterprises through equity incentive measures can boost the work enthusiasm of incentive objects and improve their work efficiency and quality. Meanwhile, a considerable proportion of remuneration for incentive objects is paid in the form of equity incentive from the profits brought about by enterprise development. This virtually reduces the cost of enterprises for commission and agency and thus leads to the reduction of human resource management cost. Certainly, equity incentive shall be implemented in a balanced manner to avoid the rise in commission and agency cost due to excessive incentive.

\subsection{Induce Financial Fraud Risks}

Aiming at equity incentive, some enterprise managers may falsify the financial reports and statements for the sake of their own private benefits, thereby rendering accounting information unauthentic. This will negatively affect company shareholders and external interested parties from accurately understanding company financial status and dampen the accuracy of decision making. The existence of such problem is a demonstration of the material-gain-oriented nature of equity incentive, and complete supervision system must be established for effective supervision. Otherwise, it will become an important reason for financial fraud, seriously disturb the management order of enterprises and harm the interests of relevant interested parties [14].

\section{Application Status of Equity Incentive in NEEQ Companies}

\subsection{Equity Incentive Status of NEEQ Companies}

In 2017, a total of 281 companies listed on the NEEQ issued 306 equity incentive plans, accounting for $2.4 \%$ of the total number of listed companies. Enterprises plan to raise 1.847 billion yuan through incentive financing, down $35.93 \%$ year-on-year, According to the number of equity incentive plans issued by neeq enterprises in each month in 2017 (As shown in figure 2), 10 plans were issued at least in February. November saw the largest number of releases, with 37.

It is foreseeable that following the development of NEEQ enterprises, the number of enterprises with equity incentive plans will continue to increase. Such situation is the result of multiple factors - it is both affected by the nature of NEEQ enterprises and induced by the effects of equity incentive. Equity incentive has become an important incentive means of NEEQ enterprises and plays a significant role in the incentive management of NEEQ enterprises.

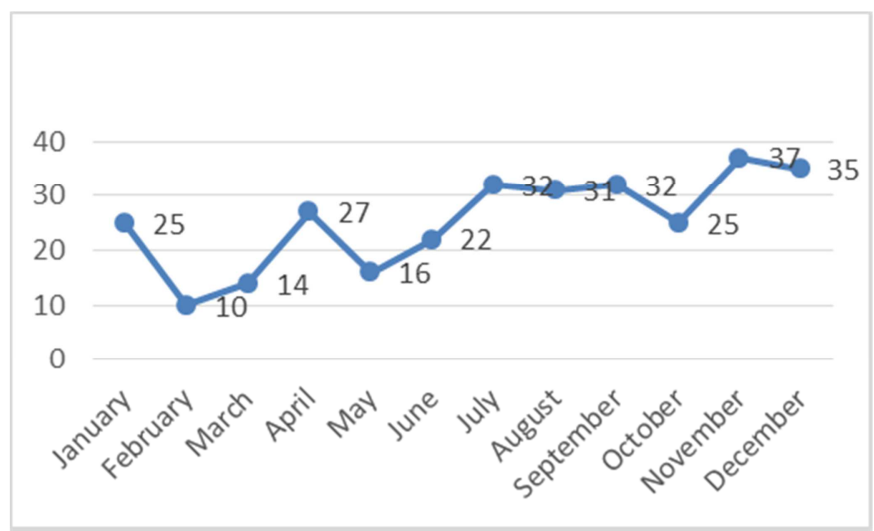

Figure 2. The number of stock incentive plans of the NEEQ was counted in 2017

\subsection{Common Equity Incentive Forms of NEEQ Companies}

According to statistics, currently restricted stock is the primary equity incentive form in NEEQ companies — out of the NEEQ companies that have adopted equity incentive plans, $49.7 \%$ of companies are implementing this form (As shown in figure 3). Meanwhile, stock option and employee stock ownership plan also take up certain proportions and are somewhat adopted in NEEQ companies. Other equity incentive forms including phantom equity, stock appreciation right and incentive fund are seldom implemented.

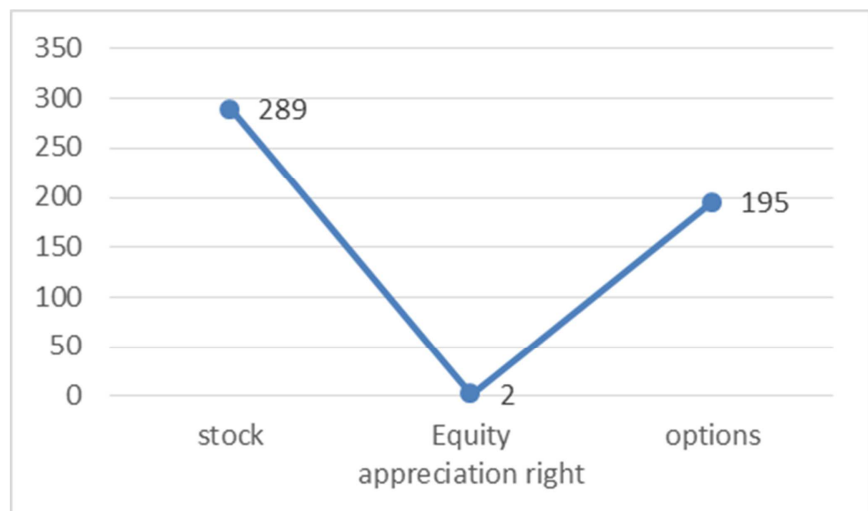

Figure 3. The number of stock incentive plans of the NEEQ was counted in 2017.

\section{Analysis of the Reasons for NEEQ Companies to Adopt Equity Incentive Measures}

The adoption of equity incentive in NEEQ companies is the result of the combination of multiple factors, and there is good suitability between the two. Specifically speaking, NEEQ companies are mainly domestic high-tech enterprises with relatively smaller staff size, asset size and operation 
scale. The core competitive power of these enterprises is mainly their technologies, but in order to keep up their technologies, they need corresponding talents. This enables the incentive mechanism to become a significant part of these enterprises' management work and makes it more important to these enterprises than to ordinary enterprises [15]. Therefore, NEEQ enterprises have an urgent need for advanced incentive measures. However, due to their weak economic foundation, NEEQ enterprises can only conduct remuneration advance through the method of equity incentive and rely on the economic increase brought about by enterprise development to provide generous rewards to high-tech talents and management personnel. Meanwhile, equity incentive is also an important means to achieve risk sharing between enterprises and incentive objects. In conclusion, as equity incentive suits NEEQ enterprises well and satisfies the status and development needs of NEEQ companies, currently it is the most reasonable incentive measure.

\section{Analysis of Problems Facing NEEQ Companies in Equity Incentive}

\subsection{Lack of Unified Standards for Equity Incentive Plans}

At present, most equity incentive plans are autonomously launched by NEEQ companies without unified constraining standards, which has resulted in many loopholes and irregularities, seriously affected the incentive effects of equity incentive plans and even given rise to ultra-low-price incentive or excessive incentive. This will negatively affect the interests of companies and incentive objects, cause serious potential hazards and become the fundamental reasons for the contradictions and disputes between enterprises and incentive objects.

\subsection{Unclear Delimitation of Equity Incentive Objects}

Analyzing from the definition and effects of equity incentive, equity incentive objects shall be limited to internal employees of enterprises. Equity incentive plans are designed for unifying the work demands of internal employees and the development objectives of enterprises and bringing the roles of individuals in boosting enterprise development into play. However, in actual practice, many enterprises include external groups and personnel including supervisors and dealers into the scope of equity incentive objects and formulate special equity incentive plans to motivate the above-mentioned groups and personnel. The situation is an autonomous conduct of enterprises and there is the necessity for them to exist, but it is somewhat different from the original purpose of equity incentive. There shall be a strict delimitation to avoid such situation to the greatest extent.

\subsection{Substantial Shareholders Increase Stake Through Equity Incentive}

Many NEEQ enterprises have a relatively small size, and their operational and managerial activities were undertaken by a single or several shareholders. Many shareholders will resort to equity incentive plans to increase their stake in the companies, which is harmful to the interests of other shareholders. This situation is not what equity incentive is meant to do. From the perspective of its essential target, equity incentive shall mainly be used for the following two aspects: First, for handling possible moral risks between shareholders and managers and effectively tying the interests of managers and enterprises together. Second, give long-term incentive to backbone business personnel to retain and stimulate backbone talents. At that point, it is absolutely not a reasonable measure to increase shareholding ratio of shareholders by stock ownership incentive.

\subsection{Under-pricing of Stock Prices in Equity Incentive}

In most cases the stock prices for equity incentive are determined by companies and incentive objects through consultation and there are no unified constraining standards and regulations, giving rise to the randomness of stock share pricing. Share prices are often priced at RMB 1 per share. This has dampened the effects of equity incentive and made it become benefits in a disguised form.

\section{Strategies for Improving Equity Incentive of NEEQ Companies}

\subsection{Launch NEEQ Equity Incentive Management System as soon as Possible}

Equity incentive is a bilateral conduct between NEEQ companies and incentive objectives and is subject to relatively less constraints and restrictions. This has become the fundamental cause for the disorderliness of equity incentive. In order to bring the disorderliness of NEEQ companies' equity incentive under control, it is necessary to establish a unified and complete management system to effectively restrain and supervise equity incentive conducts, achieve the standardization of equity incentive, prevent all kinds of unreasonable equity incentive conducts, bring the positive roles of equity incentive into full play and boost the healthy development of enterprises.

\subsection{Establish Diversified Equity Incentive System}

The current forms of equity incentive adopted by NEEQ companies are relatively unitary — the three forms of stock option, restricted stock and employee stock ownership plan are dominant while the other forms including phantom equity, incentive fund and stock appreciation right are seldom adopted, resulting in the mismatch between equity incentive forms and companies' incentive needs. In view of the situation, the development of equity incentive system shall be initiated based on the development status of NEEQ companies, so that a diversified equity incentive system can be established to satisfy the demands from different levels and individuals. 


\subsection{Moderately Implement Equity Incentive}

The essential purposes of equity incentive are to make incentive objects devote themselves to enterprise development by tying their interests and enterprises' interests together through diversified equity incentive plans, and to achieve a win-win pattern under which enterprises can get development momentum and incentive objects can acquire corresponding equity returns by achieving corresponding operation and management objectives. However, during the application of equity incentive, special considerations must be taken to ensure that equity incentive is implemented in a moderate way, to avoid the negative effects of excessive incentive or ultra-low-price incentive on the equity incentive practice.

\section{Conclusion}

Through the analysis above, we can see that there are relatively few companies using equity incentive in the NEEQ listed companies. In addition, most companies listed on the NEEQ that use equity incentive adopt restricted stock method, and the equity incentive method is relatively simple.. In the process of implementing equity incentive in the NEEQ listed companies, there are some problems, such as unclear object definition, abuse of equity incentive by large shareholders. Under such circumstances, the regulatory system for the NEEQ listed companies will promote the implementation of equity incentives in the NEEQ market, abuse of equity incentives by large shareholders, improve the overall corporate governance level of the management of listed companies, and extend the supervision and training of listed companies. Meanwhile, improving the bidding mechanism as soon as possible in the NEEQ market and lowering the threshold of investors properly will promote the liquidity of the NEEQ market and enrich the options of equity incentive methods in the NEEQ market.

\section{References}

[1] Nan Xia. Tax-related Analysis Series for Individual Income Tax on NEEQ Businesses - Equity Incentive [J]. Finance and Accounting for International Commerce, 2016 (3): 57-60.
[2] An Tan. Research on Equity Incentive of NEEQ Listed Companies [D]. Yunnan University of Finance and Economics, 2017.

[3] Di Zhang. Preliminary Analysis of "NEEQ" Equity Incentive [J]. Time Report: Academic Version, 2016 (3): 177.

[4] Wenxiong Hu. Preliminary Exploration for Equity Incentive of NEEQ Companies [C]//Century Star Innovative Education Forum. 2016.

[5] Bin Li, Yabo Zhou, Jinbo Zhu. Ten Rules for Equity Incentive [J]. Enterprise Management, 2016 (2): 65-69.

[6] Li Han. Preliminary Analysis of Enterprise Equity Incentive Plans Before Listing (NEEQ Listing) [J]. Manager Journal, 2015 (1).

[7] Yating Yu. Research on Equity Incentive System of NEEQ enterprises [D]. East China University of Political Science and Law, 2017.

[8] Wenjun Duan. Influence of equity incentive on corporate performance of NEEQ listed companies -- a case study of T company [J]. Business accounting, 2018 (22): 37-38.

[9] Yan Li. Equity incentive scheme design and tax-related research of NEEQ enterprises [J]. Tax payment, 2018 (20): 181.

[10] Yang Song. On the equity incentive system of NEEQ enterprises [J]. China international finance and economics (English and Chinese), 2018 (09): 148-149.

[11] Jizhong Li. Risk prevention analysis of financial information disclosure of listed companies [J]. Times finance, 2017 (03): $128+140$.

[12] Changming Liu, Zhipeng Cao. Analysis on current situation and countermeasures of equity incentive in China's NEEQ companies [J]. Tax payment, 2017 (22): 110-111.

[13] Pengfei Zhang. Analysis of the equity incentive scheme implemented by the companies before the NEEQ listing [J]. China business review, 2017 (17): 99-100.

[14] Chen $\mathrm{Su}$, Lin Hu. Discussion on the improvement of equity incentive mechanism in NEEQ [J]. Economic and trade practice, 2017 (04): 1-5.

[15] Hongri Tang, Yingshi Liang, Tingting Lin, Mei Yang, Liling Li. Design and Application of Equity Incentive Scheme for NEEQ Company [J]. Rural Economy and Technology, 2017, 28 (08): $115-116$. 